Egyptian Poultry Science Journal

http://www.epsaegypt.com

ISSN: 1110-5623 (Print) - 2090-0570 (On line)

\title{
GROWTH PERFORMANCE, REDOX STATUS AND ANTIBODY TITERS AGAINST NEWCASTLE DISEASE VIRUS IN BROILER CHICKENS FED EXCESSIVE DIETARY VITAMIN E UNDER HEAT STRESS CONDITIONS
}

M. A. M. SAYED ${ }^{1}$; and A. A. ABUOGHABA ${ }^{2}$

${ }^{1}$ Dep. of Poul. Prod., Fac. of Agric., Assiut Uni., Assiut, Egypt. 71515

${ }^{2}$ Dep. of Poul. Prod., Fac. of Agric., Sohag Uni., Sohag, Egypt. 82524

Corresponding author: Ahmed Abdel-kareem Abuoghaba; E-mail: Abuoghaba@yahoo.com

Received:11/01/2017 Accepted:12/02/2017

\begin{abstract}
This experiment aimed to study the effect of supplementation excessive level of vitamin $\mathrm{E}(1000 \mathrm{mg} / \mathrm{kg}$ diet $)$ on growth performance of broiler chickens under heat stress conditions. One hundred and fifty Cobb broiler chicks, 14 days old, were divided into three equal groups. Chicks in the 1st group were fed on the commercial basal diet; while those in the $2^{\text {nd }}$ and $3^{\text {rd }}$ groups were fed the same diet with adding 200 and $1000 \mathrm{mg}$ Vit. E/kg diet, respectively. Broilers had free access to feed and fresh tap water. Broilers were raised under 32 and $30^{\circ} \mathrm{C}$ during the first and second weeks, respectively, while the broilers were reared under natural ambient temperatures from 2-5 weeks of age. The broilers in the different groups were daily exposed to continuous lighting program.

The obtained results showed that the broilers in the $2^{\text {nd }}$ group tended to have higher daily weight gain $(\mathrm{p}=0.056)$ in addition they significantly improved feed conversion ratio (FCR; $\mathrm{p}<0.01$ ) compared to the other groups during the period 28-35 days of age. At 35 days of age, broilers in the $2^{\text {nd }}$ group had heavier live body weights $(\mathrm{p}<0.05)$ compared to control.

Broilers in the $2^{\text {nd }}$ group $(200 \mathrm{mg} / \mathrm{kg}$ diet $)$ significantly enhanced $(\mathrm{p}<0.05)$ plasma total antioxidant capacity $(\mathrm{p}<0.05)$ compared to the other groups. Plasma malondialdehyde concentrations for broilers in the $2^{\text {nd }}$ and $3^{\text {rd }}$ groups were decreased compared to control group. The higher antibody titers against Newcastle Disease Virus in the serum were observed at 30 days of age in the $200 \mathrm{mg}$ Vit. E/ $\mathrm{kg}$ group compared to the other treatment groups. $\mathrm{H} / \mathrm{L}$ ratio, plasma cholesterol, and glucose concentrations were insignificantly differed among treatment groups.

In general, it could be concluded that the excessive vitamin E supplementation during summer reduces its effect for maximum performance, while the better antioxidant capacity and higher antibody titers were achieved by adding the lower level (200 $\mathrm{mg}$ Vit. E/kg diet).
\end{abstract}

Keywords: Vitamin E- Broilers- Growth performance- Redox status- Heat stress. 


\section{INTRODUCTION}

High generation of free radicals (FR) and reactive oxygen species (ROS) are considered one of the consequences of exposure to heat stress, which are detrimental to the integrity of cell membranes and macromolecules (Lin et al., 2006). These consequences may cause decreased protein synthesis and increased cell apoptosis that can eventually inhibit normal growth (Mujahid et al., 2005).

In mammals and birds, the body is equipped with several enzymatic antioxidant defense systems such as catalase, superoxide dismutase and glutathione peroxidase and these acts as scavengers, protecting cells and tissues from FR and ROS attacks (Surai, 2002). This defense systems work in harmony with other antioxidants obtained from the feed such as tocopherols, retinols and ascorbic acid to accommodate any increase in the concentrations of FR and ROS. In some cases, during acute and chronic stress, the balance between antioxidants and ROS is disrupted due to the increased generation of the latter reaching concentrations that cannot be accommodated by the antioxidant defense system and eventually the imbalance can lead to cellular damage. Lipid peroxidation is the major downstream result of FR and ROS reaction with polyunsaturated fatty acids in cellular membranes (Novo and Parola, 2008; and Upston et al., 1999). The extent of lipid peroxidation can be evaluated by measuring the concentrations of the end products of the reaction such as malondialdehyde (MDA). Vitamin E is attached to lipid bilayer of cellular membranes, protecting the poly unsaturated fatty acids and consequently reducing the free radical attacks. Therefore, vitamin $\mathrm{E}$ is considered the most important antioxidant acting to protect the polyunsaturated fatty acids in cellular membrane from free radical attacks (Surai, 2002). The dietary concentrations of vitamin $\mathrm{E}$ in poultry diets vary between 2 to $15 \mathrm{mg} / \mathrm{kg}$ depending on the choice of feed ingredients and the amount and type of fat being used (Surai, 2002). Under normal conditions, dietary concentrations of antioxidants might be sufficient to obtain maximal performance. To obtain maximum performance, poultry should be provided by diets containing at least 10 $\mathrm{mg}$ vitamin $\mathrm{E} / \mathrm{kg}$ diet.

However, additional antioxidants need to be added to poultry diets under stressful conditions (Whitehead and Portsmouth, 1989). Under thermo-neutral temperature, Bartov and Frigg (1992) observed that dietary vitamin $\mathrm{E}$ at a concentration of 24 $\mathrm{mg} / \mathrm{kg}$ feed was sufficient to obtain optimal performance.Increasing dietary concentrations of $\alpha$-tocopherol by adding 10,30 and $150 \mathrm{mg}$ vitamin $\mathrm{E} / \mathrm{kg}$ diet failed to improve performance in chicks and turkeys (Friedman et al., 1998). Similar results were reported by Leonel et al. (2007) in broiler chickens when vitamin $\mathrm{E}$ was added to the diet (300 $\mathrm{mg} / \mathrm{kg}$ ).

Sahin et al. (2002a) observed linear increases in feed intake and live body weight and linear improvements in FCR by increasing dietary vitamin $\mathrm{E}$ concentration form 0 to $250 \mathrm{mg} / \mathrm{kg}$ diet. The authors couldn't find any additional improvements in growth performance when vitamin $\mathrm{E}$ levels were higher than $250 \mathrm{mg} / \mathrm{kg}$ diet. They concluded that a $250 \mathrm{mg} / \mathrm{kg}$ of vitamin $\mathrm{E}$ was optimal supplementary level for achieving maximal performance under such conditions.

A growing body of evidence shows that increasing dietary vitamin $\mathrm{E}$ concentrations improves redox status and prevents some major diseases such as cancer (Crisostomo et al., 2007). Nevertheless, recent findings have highlighted a potential risk associated with excessive dietary vitamin $\mathrm{E}$ concentrations that could lead to increased morbidity and 
mortality (Crisostomo et al., 2007). Friedman et al., (1998) concluded that optimal dietary vitamin $\mathrm{E}$ might improve protection against oxidation, but where dietary concentrations exceed this requirement, the physiological properties might revert from antioxidant to prooxidant and this could impair humoral immunity by decreasing circulating antibody levels.

This study aimed to evaluate the effects of adding vitamin $\mathrm{E}$ at moderate $(200 \mathrm{mg} / \mathrm{kg})$ and excessive $(1000 \mathrm{mg} /$ $\mathrm{kg}$ diet) levels on growth performance, total antioxidant capacity, lipid peroxidation, some stress parameters and antibody production specific for Newcastle disease virus in broiler chickens reared under high ambient temperature.

MATERIALS AND METHODS Bird managements and treatments

This experiment was performed in the Research Poultry Farm, Faculty of Agriculture, Assiut University, Assiut, Egypt.

One hundred and fifty Cobb broiler chicks were allocated to groups and housed in deep litter pens. Broilers were raised under continuous lighting program and brooding temperatures starting at $32^{\circ} \mathrm{C}$ for the first week and then reducing the temperature to $30^{\circ} \mathrm{C}$ during the second week. From 2-5 weeks of age, broilers were exposed to the natural ambient temperatures as presented in Table 1. Birds were provided with a corn-soybean commercial diet $(220 \mathrm{~g}$ protein $/ \mathrm{kg}$, $3100 \mathrm{kcal} / \mathrm{kg}, 9 \mathrm{~g}$ calcium $/ \mathrm{kg}, 4.5 \mathrm{~g}$ phosphorus $/ \mathrm{kg}$ and $40 \mathrm{mg}$ Vit. E/kg diet). At two weeks of age, birds were individually weighed, wing banded and allocated to 15 pens (10 birds/ pen) according to body weight. At one, 14 and 21 days of age, the chicks were immunized against Newcastle Disease Virus.

\section{Treatments}

At 14 days of age, chicks were divided into 3 equal groups (each with 5 replicates of 10 birds per pen) according to their body weights. In the $1^{\text {st }}$ group (control), the chicks were fed on the commercial basal diet, while those in both of $2^{\text {nd }}$ and $3^{\text {rd }}$ groups they were fed on the same diet with adding 200 and $1000 \mathrm{mg}$ Vit. E/ kg diet, respectively.

Experimental measurements and sample collection

The indoor maximum and minimum ambient temperatures $\left({ }^{\circ} \mathrm{C}\right)$ were daily recorded at 2:00 am and 11:00 pm using an electronic digital thermometer (Table 1).

Individual body weights and feed intake were recorded at 14, 21, 28 and 35 days of age. Feed conversion ratio for chicks in the treatment groups was calculated weekly, while the mortality was monitored daily.

Blood samples were collected from brachial vein from two birds in five replicate pens of each treatment at 20 and 30 days of age and serum was obtained to evaluate the antibody titers against NDV. Blood samples collected at 30 days of age were divided into two aliquots. EDTA was added to one aliquot and used for the evaluation of $\mathrm{H} / \mathrm{L}$ ratio and plasma concentrations of total antioxidant capacity, MDA, glucose and cholesterol.

The H/L ratios were evaluated by examining blood smears stained using Geimsa stain (GS500, Sigma Aldrich, St. Louis, MO). The heterophils, lymphocytes, eosinophils, monocytes and basophils) were differentially counted as described by the method according to Gross and Siegel (1983). The H/L ratio was calculated by counting 100 cells and dividing the number of heterophils by the number of lymphocytes.

Blood samples were centrifuged at 3000 rpm for 20 min and plasma was collected. Plasma concentrations of cholesterol were measured using commercial clorometric kit (Cholesterol. Liquizyme CHOD-PAP; 
Egyptian Company for Biotechnology, Cairo. Egypt). Plasma glucose concentrations were measured using commercial clorometric kit (Glucose. Liquizyme GOD-PAP; Egyptian Company for Biotechnology, Cairo. Egypt). Absorbance was monitored using a spectrophotometer (Unico UV2000, Spectra Lab Scientific Inc., USA) set at a wavelength of $545 \mathrm{~nm}$. Plasma MDA concentrations were evaluated by a commercial colorimetric kit (malondialdehyde; Biodiagnostic Co., Cairo, Egypt) according to Satoh (1978). Total antioxidant capacity was measured in the plasma of broilers by using colorimetric kit (Biodiagnostic Co., Cairo, Egypt).

Antibody titers against NDV were assessed using hemagglutination inhibition (HI) test according to the method described by Pedro Villegas (1990), while the HI titer was presented as $\log _{2}$ values of the highest reciprocal of the dilution.

\section{Statistical analysis}

The obtained data were statistically analyzed by analysis of variance using the general linear model procedure of SAS (SAS Institute, 2004) using the following fixed model: $\mathrm{Y}_{\mathrm{ij}}=\mu+\mathrm{T}_{\mathrm{i}}+$ $\mathrm{e}_{\mathrm{ij}}$

Where, $Y_{i j}$ is the $j^{\text {th }}$ observation of the $\mathrm{i}^{\text {th }}$ treatment, $\mu$ is the population mean, $T_{i}$ is the treatment effect of the $i^{\text {th }}$ treatment, and $\mathrm{e}_{\mathrm{ij}}$ is the random error. The treatment effects were considered significant when the differences between least squares means were tested at the level of $(\mathrm{p}<0.05)$ using Duncan's multiple-range test (1955).

\section{RESULTS}

\section{Growth performance}

The effects of vitamin $\mathrm{E}$ supplementation on growth performance are presented in Tables 2 and 3.

During the period 14-21 days of age, the daily weight gain, feed intake and feed conversion ratio for broilers did not differ among treatment groups. Broilers supplemented with $200 \mathrm{mg}$ Vit. E/kg tended to have better FCR compared to their controls during the period 21-28 days of age $(\mathrm{p}=0.07)$. From 28-35 days of age, improvements in daily weight gain which almost approached significance $(\mathrm{p}=0.056)$ were noted in broilers fed on diets supplemented with $200 \mathrm{mg}$ Vit. E/kg when compared with the control group. Vitamin E supplementation improved feed conversion ratio $(\mathrm{p}<0.0001)$ with the lowest value observed in broilers supplemented with $200 \mathrm{mg}$ Vit. E/ kg. At 35 days of age, broilers supplemented with $200 \mathrm{mg}$ Vit $\mathrm{E} / \mathrm{kg}$ had higher live body weights $(p<0.05)$ compared to the control group; while, those supplemented with $1000 \mathrm{mg}$ Vit. E/kg exhibited intermediate live body weights. The number of mortality was small. Only 6 birds from all treatments $(4 \%)$ died due to heat stress exhaustion, which did not differ among treatment groups.

\section{Redox status and stress measures}

The effects of vitamin E supplementation on total antioxidant capacity, MDA, glucose, and cholesterol concentrations in plasma and $\mathrm{H} / \mathrm{L}$ ratio are shown in Figures $1,2 \& 3$.

Broilers offered a diet supplemented with $200 \mathrm{mg}$ Vit. E/kg had greater total antioxidant capacity in plasma when compared to the control group, while those supplemented with $1000 \mathrm{mg}$ Vit. $\mathrm{E} / \mathrm{kg}$ had intermediate values. Both supplementary vitamin E levels decreased MDA concentrations in plasma. The H/L ratio as well as glucose and cholesterol concentrations in the plasma were not affected due to Vitamin E supplementation.

\section{Hemagglutination inhibition test}

At 20 days of age, there were no differences in serum antibody levels among different treatment groups (Figure 4). However, at 30 days of age, it was observed that broilers supplemented with $200 \mathrm{mg}$ Vit. E/kg in their diet had higher 
antibody titers against NDV compared to the rest of treatment groups (Figure 4).

\section{DISCUSSION}

\section{Growth performance}

Supplementing the diet with vitamin E did not improve growth performance during the periods 14-21 and 21-28 d except that there was a tendency for broilers supplemented with $200 \mathrm{mg}$ Vit. E/ kg to enhanced feed conversion ratio during the period 21-28 d. Nevertheless, improvements in daily weight gain and feed conversion appeared in broilers supplemented with $200 \mathrm{mg}$ Vit. E/ $\mathrm{kg}$ during the period 28-35 d which was reflected on their body weight at 35 days of age. Our results are consistent with reports showing significant improvements in daily weight gain and FCR of heat stressed broilers, laying hens and quails when fed diets supplemented with different types of antioxidants (Sahin et al., 2001, Sahin et al., 2002b, Sahin et al., 2003 and Sahin et al., 2006).

Antioxidants are thought to improve performance by minimizing the oxidative damage that occurs in animal cells and tissues following hyperthermia-induced FR and ROS production. These reactive agents are capable of promoting cell aging and apoptosis which might inhibit normal growth and increase mortality rates (Mujahid et al., 2005).

It appears that the degree of cellular damage caused by FR and ROS depends on the degree of stressful condition experienced by the birds. The higher the thermal stress, the greater will be the potential for oxidative damage to cells. The current results may suggest that the ambient temperature was not high enough during the first and second periods (1421 and 21-28 d) to induce oxidative stress. In addition, any increase in FR and ROS generation can be accommodated, to some extent, by the cell increasing the synthesis of antioxidant enzymes such as SOD. For instance, a two-fold increase in SOD activity produces a several hundred-fold increases in cell survival (Loven, 1988). Lin et al., (2004) evaluated the effects of long-term dietary administration of corticosterone, to mimic induction of physiological stress, on the redox status in broiler chickens. These workers observed an initial increase in lipid peroxidation following corticosterone administration, which was attenuated later by increased concentrations of non-enzymatic antioxidants. In a further study, a significant increase in plasma total antioxidant capacity coincided with an increase in the activity of SOD in heart tissue following short-term administration of corticosterone in broilers. These regulations in antioxidant levels resulted in decreased lipid peroxidation of plasma while lipid peroxidation in heart and liver tissues was unaffected (Lin et al., 2004).

On the other hand, as the broilers' age and weight increased, the antioxidant content of the basal diet was not adequate to accommodate the increased thermal load on the birds which resulted in increased oxidative damage with a consequential negative effect on growth performance. This assumption may explain the late improvements seen in daily weight gain and FCR in broilers fed a diet supplemented with $200 \mathrm{mg}$ Vit. E/kg.

\section{Redox status}

High ambient temperature is reported to increase the generation of FR and ROS which can cause a cascade of detrimental reactions within cellular membranes and to macromolecules eventually leading to cell death (Loven, 1988; Flanagan et al., 1998; Altan et al., 2000, Sahin et al., 2001, 2003, Surai, 2002, Mujahid et al., 2005, 2006 and 2007). The breakdown of polyunsaturated fatty acids in cellular membranes (lipid peroxidation) is considered to be the main consequence of free radical toxicity in biological cells. 
Malondialdehyde (MDA) is main degradation product of lipid peroxidation and is widely used as a measure of the degree of lipid peroxidation (Altan et al., 2000; Sahin et al., 2001 and 2003).

Vitamin E supplementation at levels of 200 and $1000 \mathrm{mg} / \mathrm{kg}$ diet resulted in reduced MDA concentrations in plasma compared with that of the control. This might suggest a reduced degree of lipid peroxidation and consequently an improved redox status during heat stress. Vitamin $\mathrm{E}$ is known to prevent the propagation of the lipid peroxidation induced by free radical and reactive oxygen species. Vitamin $\mathrm{E}$ acts to protect the polyunsaturated fatty acids in the lipid component of the cellular membranes and plasma lipoproteins (Packer et al., 2001; and Upston et al., 1999).

The results here are in agreement with those of (Sahin et al., 2001; Sahin et al., 2003; and Sahin et al., 2006) who reported decreased plasma MDA concentrations in heat stressed broilers and quails following supplementation with vitamin $\mathrm{E}$, vitamin $\mathrm{A}$, ascorbic acid, and chromium.

The MDA concentrations in plasma of broilers supplemented with $1000 \mathrm{mg}$ Vit. E/kg was numerically, but not significantly, higher than those of birds supplemented with $200 \mathrm{mg}$ Vit. E/kg (3.58 vs. $2.81 \mathrm{nmol} / \mathrm{ml}$, respectively). Similarly, the data showed that the total antioxidant capacity in plasma for broilers supplemented with $200 \mathrm{mg}$ Vit. E/kg was significantly greater than that of the control birds with intermediate values for broilers supplemented with $1000 \mathrm{mg}$ Vit. E/kg. These findings suggest that increasing vitamin $\mathrm{E}$ in the diet, beyond the recommended levels, may reduce its efficiency in protecting cellular membranes and macromolecules against oxidative stress.
Mahmoud and Hijazi (2007) imposed an oxidative stress in broiler chickens by inter peritoneal injection of carbon tetrachloride to evaluate the effects of vitamin $\mathrm{A}$ and/or $\mathrm{E}$ supplementation on plasma enzymatic antioxidants and total antioxidant capacity. The researchers reported a $33.6 \%$ decrease in total antioxidant capacity 24 hours postinjection in control birds fed on basal diets. This effect was lessened in broilers fed the diet containing 20 and $40 \mathrm{mg}$ vitamin $\mathrm{E} / \mathrm{kg}$ diet. In another study, the formation of lipid peroxidation in broiler chickens induced by subcutaneous injection of dexamethasone was suppressed due to vitamin E supplementation $(200 \mathrm{mg} / \mathrm{kg})$ as it significantly lowered the Thiobarbituric Acid Reactive Substances (TBARS) levels in plasma and skeletal muscle tissue (Gao et al., 2010). In spite of the favorable influence of vitamin E on TBARS levels, the authors could not observe any effects on the total antioxidant power due to vitamin $\mathrm{E}$ supplementation in injected birds.

Maintaining the integrity of cellular components from oxidative damage is a function of the body enzymatic and nonenzymatic antioxidant systems. Thus, evaluation of the total antioxidant capacity is more comprehensive than assaying a single antioxidant when assessing the redox status (Mahmoud and Hijazi, 2007). Meanwhile, we should bear in mind the cellular compensatory mechanisms that may occur in response to exposure to an oxidative stress which may include upregulation or increased activity of a certain enzymatic antioxidant or an increased level of a non-enzymatic antioxidant. These mechanisms may account for the discrepancies reported in the literature regarding the levels of total antioxidant capacity when studying the effects of a certain antioxidant. 


\section{Stress measures}

Exposure to high ambient temperatures stimulates the hypothalamic-pituitaryadrenal axis with a consequential increase of corticosterone secretion (Zardooz et al., 2006). The increased secretion of corticosterone, together with catecholamine and glucocorticoids, induces glycogenolysis in the liver resulting in increased glucose levels in the blood (Donaldson et al., 1991). Not only glucose but other biochemical in plasma such as cholesterol, triglycerides and high-density lipoproteins are also affected by exposure to stressor types (Puvadolpirod and Thaxton, 2000a). Hence, the changes in cholesterol and glucose levels in plasma are used as indicators of stress in domestic poultry (Mumma et al., 2006).

Furthermore, exposure to stress changes the number of heterophils and lymphocytes causing increases in their ratio (Gross and Siegel, 1983; Siegel, 1995; and Vleck et al., 2000), which is used either as a stress measure.

In the current study, there were no differences in $\mathrm{H} / \mathrm{L}$ ratio and plasma concentrations of glucose and cholesterol among the treatment groups due to vitamin $\mathrm{E}$ supplementation.

Our results are in line with those reported by Sayed and Downing (2009), but contradict those of others who have observed a linear reduction in serum glucose and cholesterol concentrations in broilers fed diets supplemented with vitamin E under high ambient temperature (Sahin et al., 2001 and 2002a).

\section{Antibody titers}

Although we could not find any differences in humoral immunity among different treatment groups at 20 days of age, higher antibody titers were noticed in the group supplemented with $200 \mathrm{mg}$ Vit. E/kg compared to the other treatment groups at 30 days of age. It is well known that the younger birds are less affected by high ambient temperature than older birds. Therefore, the thermo-neutral zone for poultry species declines as the bird ages and grows.

Therefore, poultry producers rarely worry about heat distress with young poultry (less than 4 weeks old). Heavier and fast growing breeds generally have more of a problem with heat stress because they have less surface area for heat dissipation per unit weight (Teeter and Belay, 1996). For instance, under elevated temperatures, a broiler that weighs $1.8 \mathrm{~kg}$ consuming $620 \mathrm{kcal} \mathrm{ME} / \mathrm{d}$, needs to dissipate around $380 \mathrm{kcal} \mathrm{ME} / \mathrm{d}$ to the surrounding air, which is higher than the daily intake (310 $\mathrm{kcal} \mathrm{ME} / \mathrm{d}$ ) of a laying hen of the same weight (Gous and Morris, 2005). The increased thermal burden on the birds, as they age, may cause impairment of the immune function.

The results of Zulkifli et al. (2000) and Mashaly et al. (2004) showed that the antibody production was reduced when broiler chickens and laying hens exposed to high temperature.

An accumulated body of evidence shows that increasing dietary vitamin E levels enhances the immune competence of chickens (Swain et al., 2000; and Niu et al., 2009). It is thought that vitamin $\mathrm{E}$ improves humoral immunity as a result of the destruction of peroxides (Swain et al., 2000).

Our results are consistent with those of Swain et al. (2000) where higher antibody titers were noticed in vitamin Esupplemented groups (150 and 300 IU vitamin $\mathrm{E} / \mathrm{kg}$ ) compared to the control group.

Nevertheless, there are conflicting reports where no changes and depressions in antibody titers against SRBC were seen following increasing dietary vitamin $\mathrm{E}$ levels (Leshchinsky and Klasing, 2001; and Sakamoto et al., 2006). Also, the results of Friedman et al. (1998) showed that increasing dietary vitamin $\mathrm{E}$ to levels 
that exceeds NRC recommendations by 15 folds $(150 \mathrm{mg} / \mathrm{kg})$ impairs antibody But we have to bear in mind that these levels might be surplus under thermoneutral temperature. In the current study, supplementing the diet with $1000 \mathrm{mg}$ vitamin $\mathrm{E} / \mathrm{kg}$ resulted in lower antibody titers than those of birds supplemented with $200 \mathrm{mg}$ vitamin $\mathrm{E} / \mathrm{kg}$. This level is therefore excessive and has no beneficial effects for broiler production in both chick and turkey.

chickens exposed to high ambient temperature.

\section{CONCLUSION}

From the obtained results it could be concluded that supplementing broiler diets with $1000 \mathrm{mg}$ vitamin E/ $\mathrm{kg}$ diet during summer is excessive and it may reduce its role in improving bird's performance and humoral immunity.

Table (1): Average maximum and minimum indoor ambient temperatures $\left({ }^{\circ} \mathrm{C}\right)$ throughout the experimental period

\begin{tabular}{|l|c|c|c|}
\hline $\begin{array}{c}\text { Ambient } \\
\text { temperature }\left({ }^{\circ} \mathbf{C}\right)\end{array}$ & $\begin{array}{c}\mathbf{3}^{\text {rd }} \text { week } \\
(\mathbf{1 4 - 2 1 d})\end{array}$ & $\begin{array}{c}\mathbf{4}^{\text {th }} \text { week } \\
\mathbf{( 2 1 - 2 8 d ) ~}^{\text {(21) }}\end{array}$ & $\begin{array}{c}\mathbf{5}^{\text {th }} \text { weeks } \\
\mathbf{( 2 8 - 3 5 d )}^{-128}\end{array}$ \\
\hline Maximum & 31.5 & 31.8 & 33.3 \\
Minimum & 26.4 & 27.2 & 28.6 \\
\hline
\end{tabular}

Table (2): The effects of additional dietary vitamin E on live body weight and daily weight gain of broilers

\begin{tabular}{|l|c|c|c|c|c|}
\hline \multirow{2}{*}{ Traits $\rightarrow$} & \multicolumn{2}{|c|}{ Body weight (g) } & \multicolumn{3}{c|}{ Daily weight gain (g) } \\
\cline { 2 - 6 } Vit. E (mg/kg) $\downarrow$ & Initial (14 d) & Final (35 d) & $\mathbf{1 4 - 2 1 d}$ & $\mathbf{2 1 - 2 8 ~ d}$ & $\mathbf{2 8 - 3 5 ~ d ~}$ \\
\hline 0 (Control) & 327.0 & $1463.0^{\mathrm{b}}$ & 42.8 & 54.6 & 61.5 \\
$\mathbf{2 0 0}$ & 329.0 & $1570.0^{\mathrm{a}}$ & 43.7 & 55.8 & 73.0 \\
$\mathbf{1 0 0 0}$ & 329.0 & $1501.0^{\mathrm{ab}}$ & 41.9 & 52.3 & 66.0 \\
Pooled SEM & 6.33 & 28.61 & 1.71 & 3.18 & 2.86 \\
Probability & 0.888 & 0.013 & 0.771 & 0.746 & 0.056 \\
\hline
\end{tabular}

$\mathrm{A}, \mathrm{b}$ for main effects, means within the same column without common superscripts are significantly different $(\mathrm{p}<0.05)$.

Table (3): The effect of additional dietary vitamin $E$ on feed intake and feed conversion ratio of broilers

\begin{tabular}{|c|c|c|c|c|c|c|}
\hline \multirow{2}{*}{$\begin{array}{c}\text { Traits } \rightarrow \\
\text { Vit. E } \\
(\mathbf{m g} / \mathbf{k g}) \downarrow\end{array}$} & \multicolumn{3}{|c|}{$\begin{array}{c}\text { Feed intake } \\
\text { (g/bird/day) }\end{array}$} & \multicolumn{3}{c|}{$\begin{array}{c}\text { Feed conversion ratio } \\
\text { (g feed/g gain) }\end{array}$} \\
\cline { 2 - 7 } & $14-21 \mathrm{~d}$ & $21-28 \mathrm{~d}$ & $28-35 \mathrm{~d}$ & $14-21 \mathrm{~d}$ & $21-28 \mathrm{~d}$ & $28-35 \mathrm{~d}$ \\
\hline 0 (Control) & 64.8 & 93.2 & 121.8 & 1.51 & 1.75 & $1.98^{\mathrm{a}}$ \\
$\mathbf{2 0 0}$ & 64.3 & 95.9 & 132.3 & 1.48 & 1.68 & $1.80^{\mathrm{c}}$ \\
$\mathbf{1 0 0 0}$ & 63.2 & 90.9 & 122.8 & 1.51 & 1.73 & $1.86^{\mathrm{b}}$ \\
Pooled SEM & 1.92 & 5.02 & 4.81 & 0.03 & 0.02 & 0.05 \\
Probability & 0.844 & 0.800 & 0.316 & 0.650 & 0.075 & 0.001 \\
\hline
\end{tabular}

$\mathrm{A}, \mathrm{b}, \mathrm{c}$ for main effects, means within the same column without common superscripts are significantly different $(\mathrm{p}<0.05)$. 


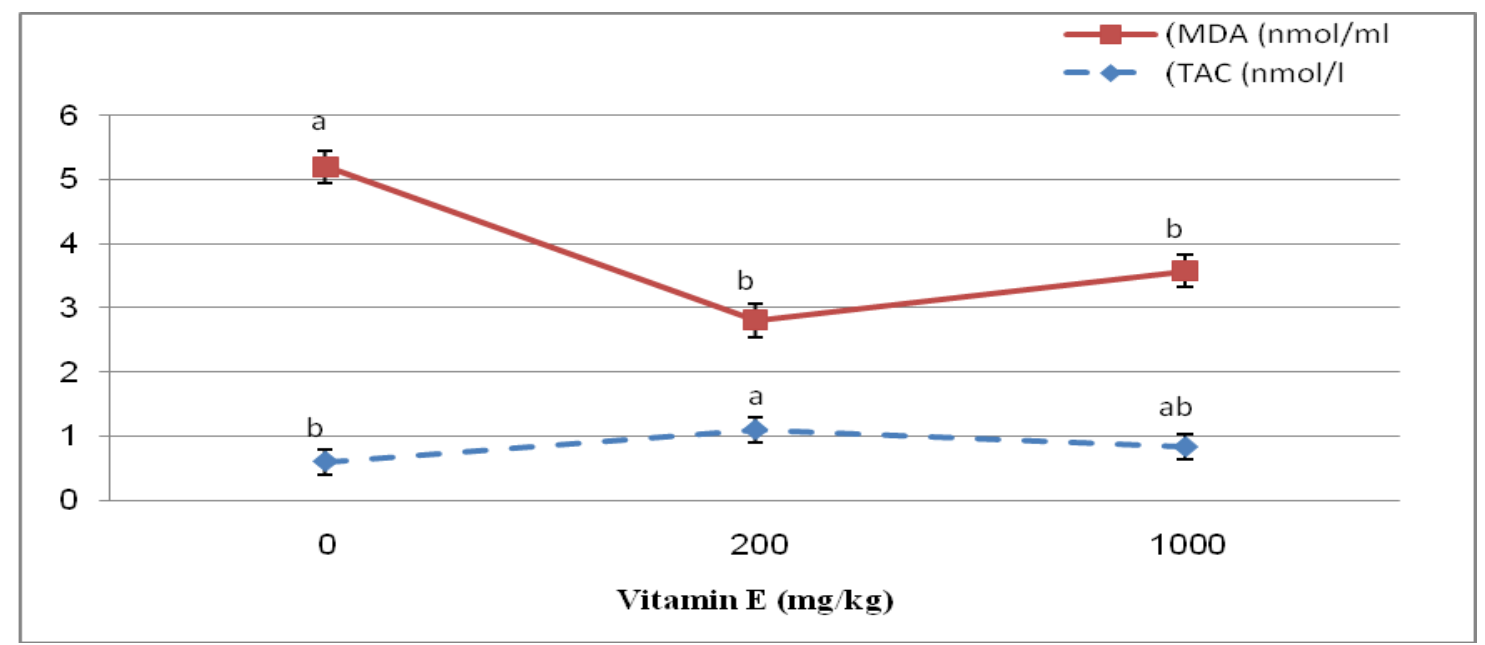

Figure 1: The effects of vitamin $\mathrm{E}$ supplementation on plasma total antioxidant capacity (TAC) and malondialdehyde (MDA) concentrations. Values are mean \pm SEM. ${ }^{a, b}$ Means with different letters differ significantly $(\mathrm{p}<0.05)$.

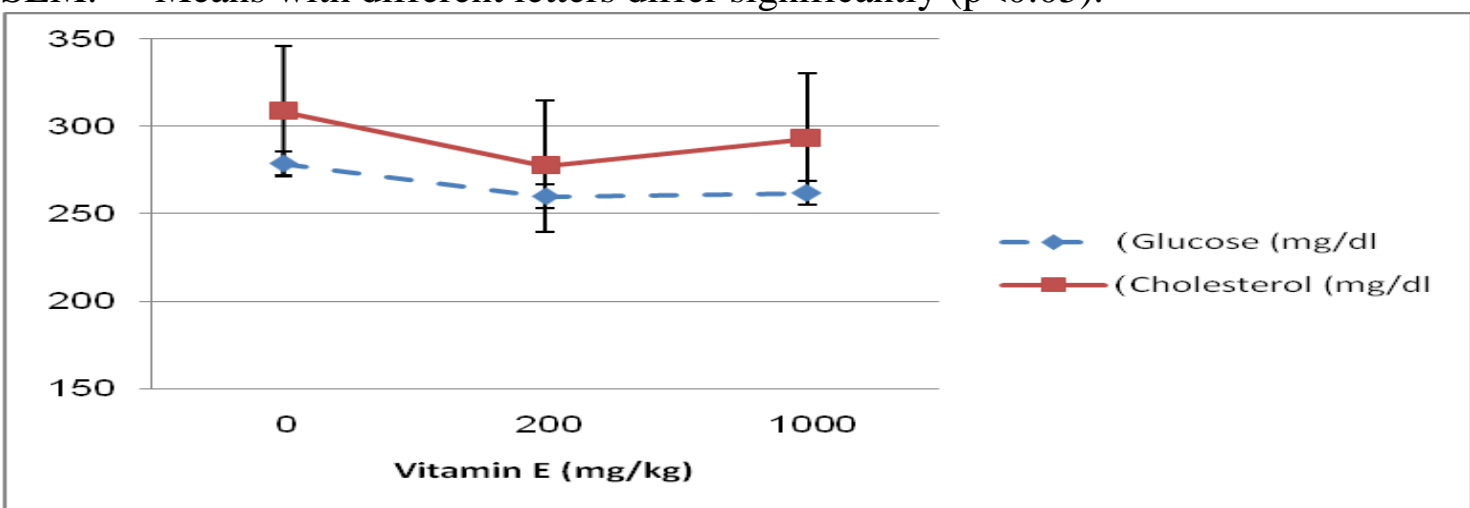

Figure 2: The effects of vitamin $\mathrm{E}$ supplementation on plasma glucose and cholesterol concentrations. Values are mean \pm SEM. ${ }^{\mathrm{a}, \mathrm{b}}$ Means with different letters differ significantly $(\mathrm{p}<0.05)$.

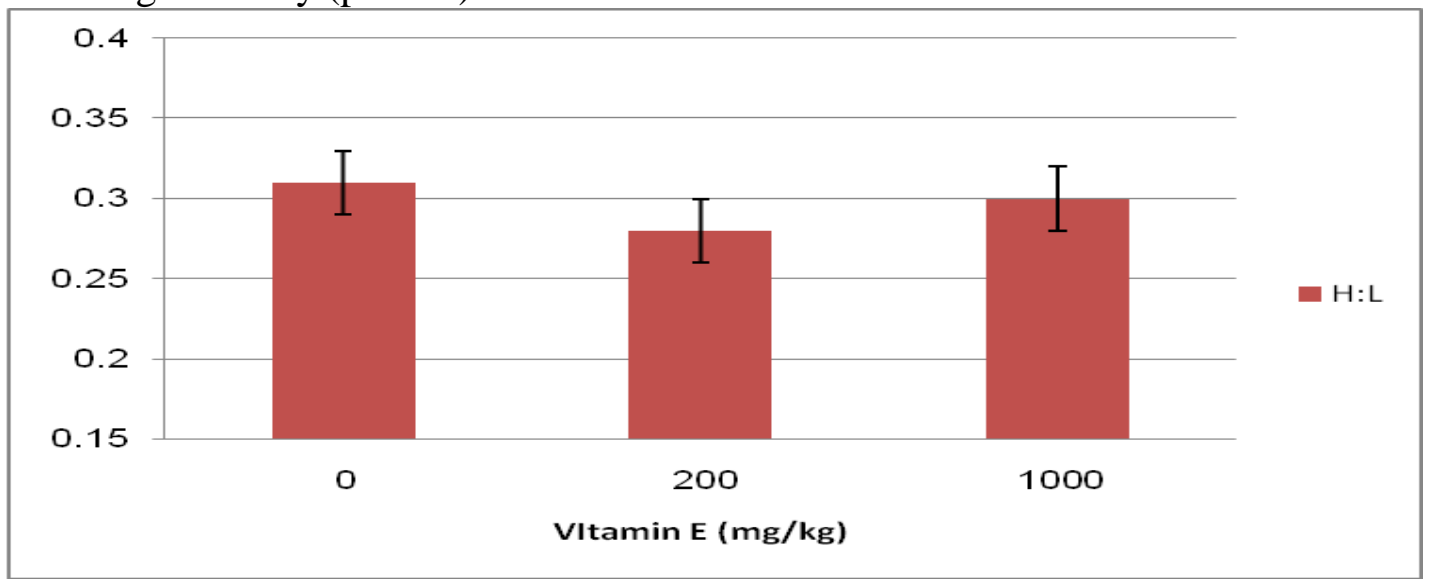

Figure 3: The effects of vitamin E supplementary level on Heterophil/ Lymphocyte $(\mathrm{H} / \mathrm{L})$ ratio. Values are mean \pm SEM. ${ }^{\mathrm{a}}{ }^{\mathrm{b}}$ Means with different letters differ significantly $(\mathrm{p}<0.05)$. 


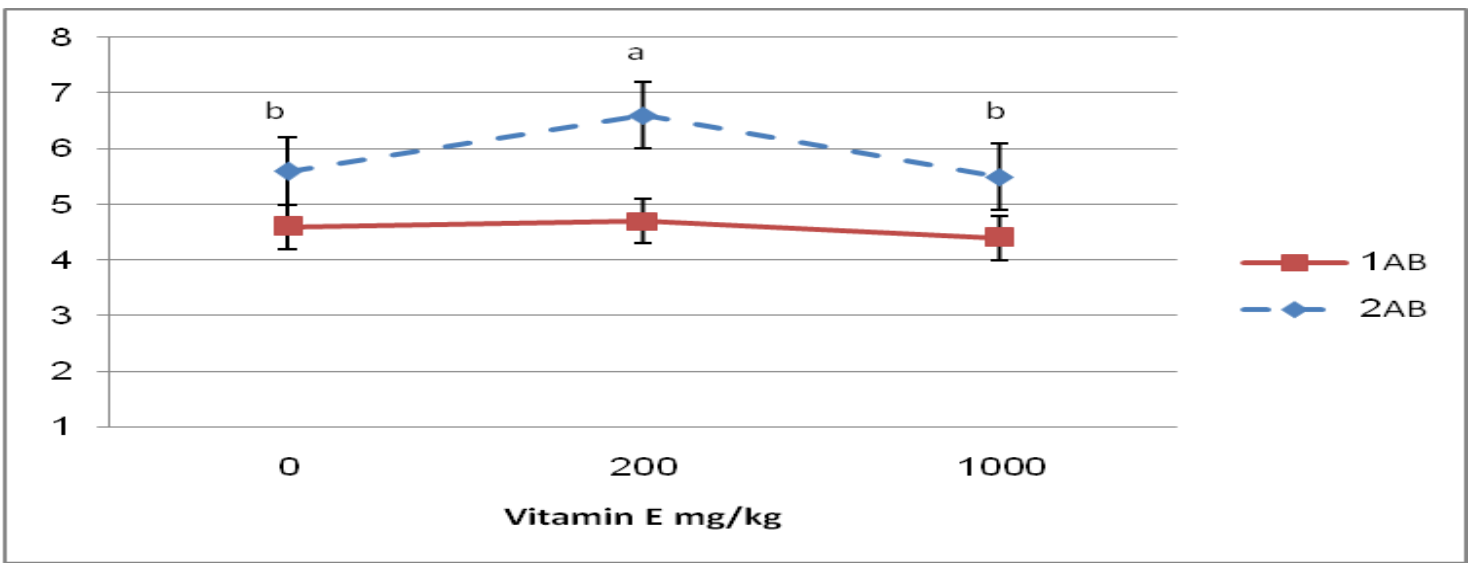

Figure 4: The effects of vitamin $\mathrm{E}$ supplementary level on serum antibody titers against Newcastle Disease Virus (HI test) at 20 and 30 days of age. Values are mean \pm SEM. ${ }^{\text {a }}$ b Means with different letters differ significantly $(\mathrm{p}<0.05)$.

$\mathrm{AB} 1=$ Antibody titers at 20 days of age.

$\mathrm{AB} 2=$ Antibody titers at 30 days of age 


\section{REFERENCES}

Altan, O.; Altan, A.; Oguz, I.; Pabuccuoglu, A.; and Konyalioglu, S., 2000. Effects of heat stress on growth, some blood variables and lipid oxidation in broilers exposed to high temperature at an early age. $\mathrm{Br}$. Poult. Sci., 41: 489-493.

Bartov, I.; and Frigg, M., 1992. Effect of high-concentrations of dietary vitamin-E during various age periods on performance, plasma vitamin-E and meat stability of broiler chicks at 7 weeks of age. Br. Poult. Sci., 33: 393-402.

Crisostomo, A. G.; Moreno, R. B.; Navaratnam, S.; Wilkinson, J. A.; and Bisby, R. H., 2007. Generation of superoxide and singlet oxygen from alpha-tocopherolquinone and analogues. Free Rad. Res., 41: 730737.

Donaldson, W. E.; Christensen, V. L.; and Krueger, K. K., 1991. Effects of stressors on blood glucose and hepatic glycogen concentrations in turkey poults. Comp. Biochem. Phys. A., 100: 945-947.

Duncan, D. B., 1955. Multiple range and multiple $\mathrm{F}$ tests. Biometrics 11: $1-42$.

Flanagan, S. W.; Moseley, P. L.; and Buettner, G. R., 1998. Increased flux of free radicals in cells subjected to hyperthermia: detection by electron paramagnetic resonance spin trapping. FEBS Letters, 431: 285286.

Friedman, A.; Bartov, I.; and Sklan, D., 1998. Humoral immune response impairment following excess vitamin E nutrition in the chick and turkey. Poult. Sci., 77: 956-962.

Gao, J.; Lin, H.; Wang, X. J.; Song, Z. G.; and Jiao, H. C., 2010. Vitamin E supplementation alleviates the oxidative stress induced by dexamethasone treatment and improves meat quality in broiler chickens. Poult. Sci., 89: 318-327.

Gous R. M.; and Morris, T. R., 2005. Nutritional Interventions in alleviating the effects of high temperatures in broiler production. World's Poult. Sci., 61: 463-475.

Gross, W. B.; and Siegel, H. S., 1983. Evaluation of the heterophil / lymphocyte ratio as a measure of stress in chickens. Avian Diseases, 27: 972-979.

Leonel, F. R.; Oba, A.; Pelicano, E. R. L.; Zeola, N.; Boiago, M. M.; Scatolini, A. M.; Lima, T. M. A.; Souza, P. A.; and Souza, H. B. A., 2007. Performance, carcass yield, and qualitative characteristics of breast and leg muscles of broilers fed diets supplemented with vitamin $\mathrm{E}$ at different ages. Braz. J. Poult. Sci., 9: 91-97.

Leshchinsky, T. V.; and Klasing, $\mathrm{K}$. C., 2001. Relationship between the level of dietary vitamin $\mathrm{E}$ and the immune response of broiler chickens. Poult. Sci., 80: 1590-1599.

Lin, H.; Decuyperea, E.; and Buysea, J., 2004. Oxidative stress induced by corticosterone administration in broiler chickens (Gallus gallus domesticus). Comparative Biochem. Physiol., 139 (B): 745 - 751.

Lin, H.; Decuypere, E. and Buyse, J. 2006. Acute heat stress induces oxidative stress in broiler chickens. Comparative Biochemistry and Physiology. A, Molecular \& Integrative Physiology 144:11-17.

Loven, D. P., 1988. A role for reduced oxygen species in heat induced cell killing and the induction of thermotolerance. Med. Hypotheses, 26: 39-50.

Mahmoud, K. Z.; and Hijazi, A. A., 2007. Effect of vitamin $A$ and/or $E$ on plasma enzymatic antioxidant systems and total antioxidant capacity of broiler chickens challenged with 
carbon tetrachloride. J. Anim. Physiol. Anim. Nutr., 91: 333-340.

Mashaly, M. M.; Hendricks, G. L.; Kalama, M. A.; Gehad, A. E.; Abbas, A. O.; and Patterson, P. H., 2004. Effect of heat stress on production parameters and immune responses of commercial laying hens. Poult. Sci., 83: 889-894.

Mujahid, A.; Yoshiki, Y.; Akiba, Y.; and Toyomizu, M., 2005. Superoxide radical production in chicken skeletal muscle induced by acute heat stress. Poult. Sci., 84: 307314.

Mujahid, A.; Sato, K.; Akiba, Y.; and Toyomizu, M., 2006. Acute heat stress stimulates mitochondrial superoxide production in broiler skeletal muscle, possibly via down regulation of uncoupling protein content. Poult. Sci., 85: 1259-1265.

Mujahid, A.; Pumford, N. R.; Bottje, W.; Nakagawa, K.; Miyazawa, T.; Akiba, Y.; and Toyomizu, M., 2007. Mitochondrial oxidative damage in chicken skeletal muscle induced by acute heat stress. J. Poult. Sci., 44: 439-445.

Mumma, J. O.; Thaxton, J. P.; Vizzier-Thaxton, Y.; and Dodson, W. L., 2006. Physiological stress in laying hens. Poult. Sci., 85: 761-769.

Novo, E.; and Parola, M., 2008. Redox mechanisms in hepatic chronic wound healing and fibrogenesis. Fibrogenesis Tissue Repair, 1:5.

Niu, Z. Y.; Liu, F. Z.; Yan, Q. L.; and Li, W. C., 2009. Effects of different levels of vitamin $E$ on growth performance and immune responses of broilers under heat stress. Poult. Sci., 88: 2101-2107.

Packer, L.; Weber, S. U.; and Rimbach, G., 2001. Molecular aspects of \{alpha-tocotrienol antioxidant action and cell signalling. J. Nutr., 131: 369S-373.

Pedro Villegas, 1990. Avian virus diseases laboratory manual.17-18, college of veterinary medicine, Athens, Georgia. 3062.

Puvadolpirod, S.; and Thaxton, J. P., 2000a. Model of physiological stress in chickens 2.Dosimetry of adrenocorticotropin. Poult. Sci.,79: 370-376.

Sahin, K.; Sahin, N.; Onderci, M.; Yaralioglu, S.; and Kucuk, O., 2001. Protective role of supplemental vitamin $\mathrm{E}$ on lipid peroxidation, vitamins $\mathrm{E}, \mathrm{A}$ and some mineral concentrations of broilers reared under heat stress. Vet. Med., 46: 140144.

Sahin, K.; Kucuk, O.; Sahin, N.; and Gursu, M. F, 2002a. Optimal dietary concentration of vitamin $\mathrm{E}$ for alleviating the effect of heat stress on performance, thyroid status, ACTH and some serum metabolite and mineral concentrations in broilers. Vet. Med. - Czech, 47: 110-116.

Sahin, K.; Sahin, N.; and Yaralioglu, S., 2002b. Effects of vitamin $C$ and vitamin $\mathrm{E}$ on lipid peroxidation, blood serum metabolites, and mineral concentrations of laying hens reared at high ambient temperature. Bio. Trace Elem. Res., 85: 91-100.

Sahin, K.; Sahin, N.; and Kucuk, O., 2003. Effects of chromium, and ascorbic acid supplementation on growth, carcass traits, serum metabolites, and antioxidant status of broiler chickens reared at a high ambient temperature (32 deg C). Nutr. Res., 23: 225-238.

Sahin, K.; Onderci, M.; Sahin, N.; Gursu, M. F.; Khachik, F.; and Kucuk, O., 2006. Effects of lycopene supplementation on antioxidant status, oxidative stress, performance and carcass characteristics in heatstressed Japanese quail. J. Thermal Bio., 31: 307-312.

Sakamoto, M. I.; Murakami, A. E.; Silveira, T. G. V.; Fernandes, J. I. M.; and Oliveira, C. A. L., 2006. Influence of Glutamine and Vitamin 
$E$ on the Performance and the Immune Responses of Broiler Chickens. Braz. J. Poult. Sci., 8: 243249.

SAS, Statistical Analysis Systems Institute, 2004. SAS/STAT user's guide: release 6.03. SAS institute Inc., Cary, NC. USA.

Satoh, K., 1978. Serum-lipid peroxide in cerebrovascular disorders determined by a new colorimetric method. Clin. Chim. Acta, 90: 37-43.

Sayed, M. A. M.; and Downing, J., 2009. Does Antioxidants Supplementation positively affect redox homeostasis and performance in broiler chickens exposed to short term heat stress? Proceedings of the 20th Australian Poultry Science Symposium, Sydney, New South Wales, Australia, 12-14 February 2009.

Siegel, H. S., 1995. Stress, strains and resistance. Br. Poult. Sci., 36: 3-22.

Surai, P. F., 2002. Natural antioxidants in avian nutrition and reproduction. Surai, P. F. (editor): Vitamin E and selenium. Nottingham University press, Nottingham, pp: 27-96, 233283.

Swain, B. K.; Johri, T. S.; and Majumdar, S., 2000. Effect of supplementation of vitamin $\mathrm{E}$, selenium and their different combinations on the performance and immune response of broilers. $\mathrm{Br}$. Poult. Sci., 41: 287-292.

Teeter, R. G.; and Belay, T., 1996. Broiler management during acute heat stress. Anim. Feed Sci. Tech., 58: 127-142.

Upston, J. M.; Terentis, A. C.; and Stocker, R., 1999. Tocopherolmediated peroxidation of lipoproteins: implications for vitamin $E$ as a potential antiatherogenic supplement. FASEB J., 13: 977-994.

Vleck, C. M.; Vertalino, N.; Vleck, D.; and Bucher, T. L., 2000. Stress, corticosterone and heterophil to lymphocyte ratios in free-living Adelie Penguins. Condor, 102: 392400.

Whitehead, C. C.; and Portsmouth, J. I., 1989. Vitamin requirements and allowances for poultry. In: Recent Advances in Animal Nutrition. Edited by Haresign, W. and Cole D. J. A., London, pp: 35-86.

Zardooz, H.; Asl, S. Z.; Naseri, M. K. G.; and Hedayati, M., 2006. Effect of chronic restraint stress on carbohydrate metabolism in rat. Phys. Behav., 89: 373-378.

Zulkifli, I.; Norma, M. T. C.; Israf, D. A.; and Omar, A. R., 2000. The effect of early age feed restriction on subsequent response to high environmental temperatures in female broiler chickens. Poult. Sci., 79: 1401-1407. 


\section{الملخص العربي}

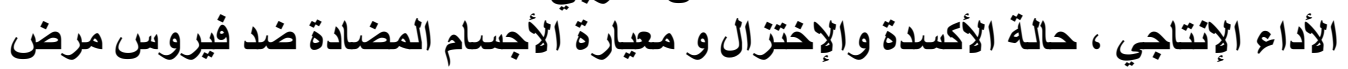

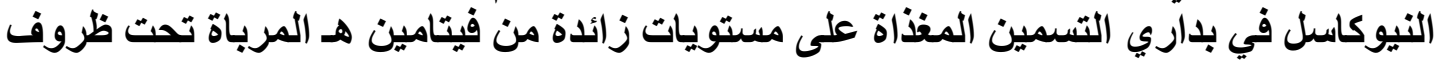

$$
\begin{aligned}
& \text { الإجهاد الحراري } \\
& \text { محمد عبدالحميذ محمد سيد1، أحمد عبدالكريم ابوغابة الزية }
\end{aligned}
$$

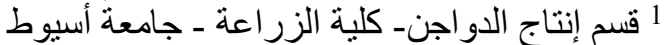

$$
\begin{aligned}
& 2 \text { قسم إنتاج الدواجن- كلية الزر اعة - جامعة سو هاج }
\end{aligned}
$$

استهذفت هذه التجربة دراسة تأثثر إضافة المستوي الزائد من فيتامين هـ (1000ملجم / كجم علف) علي الأداء

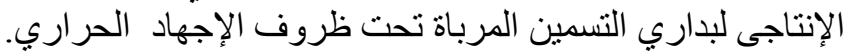

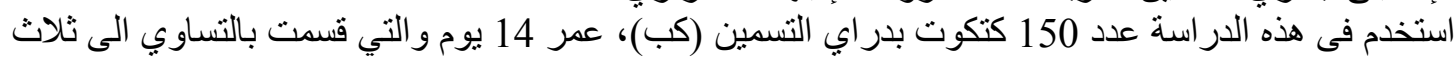

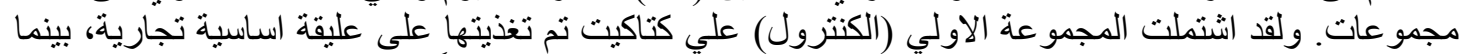
تغذت مثيلاتها بالمجموعتين الثانية والثالثة على نفس العليقة التجارية مضافاً اليها فيتامين هـ بمعدل 200 و و

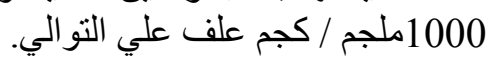

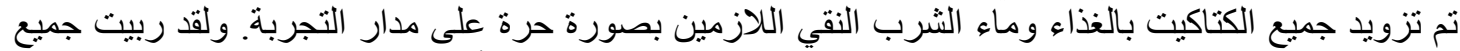

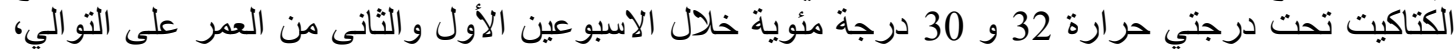

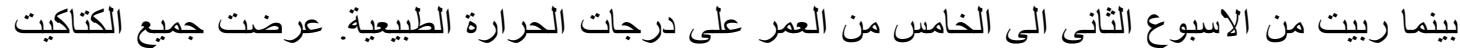

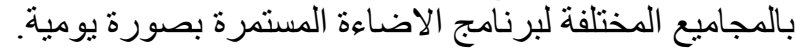

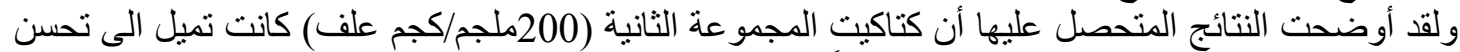

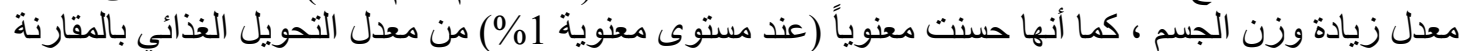

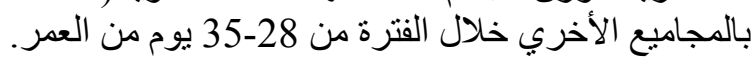

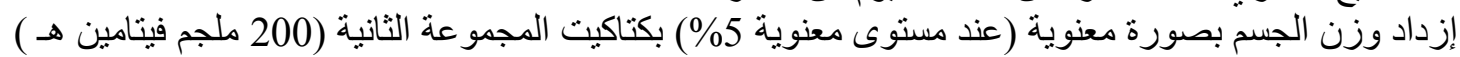
عند عمر 35 يوم مقارنة بمجمو عة الجنة الكنترول. ولقد أوضحت النتائج وجود تحسن معنوي (عند مستوى معند معنوية 5\%) بالكفاءة الكلية لمضادات الأكسدة ببلازما كتاكيت المجمو عة الثانية مقارنة بالمجمو عات الأخري. إنخفض وبصورة

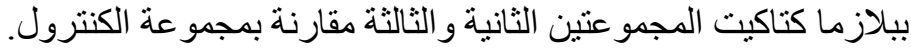

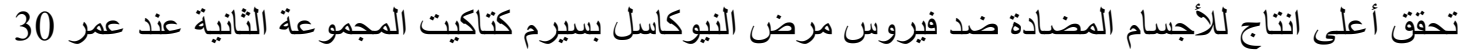
يوم بالمقارنة بكتاكيت المجاميع الأخري. هذا ولم توجد أية فروق الألماتئ معنوية بمستوى الكوليسترول بالبلازما

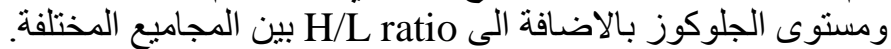

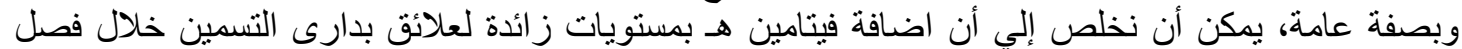

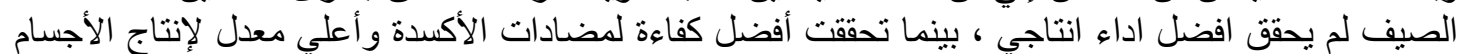

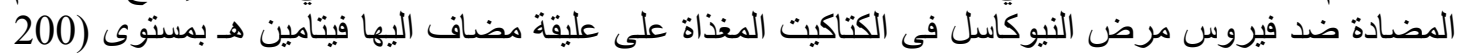
ملجم/ كجم علف). مفاتيح البحث: فيتامين هـ ، بداري التسمين ، الأداء الإتتاجي، حالة الأكسدة والإختزال ، الاجهاد الحراري. 